\title{
The analysis of alder pollen season in selected cities of Poland in 2021
}

\author{
Anna Rapiejko', Małgorzata Malkiewicz ${ }^{2}$, Tomasz Wolski ${ }^{3}$, Agata Konarska ${ }^{4}$, Monika Ziemianin ${ }^{5}$, \\ Kazimiera Chłopek ${ }^{6}$, Grzegorz Siergiejko ${ }^{7}$, Kornel Szczygielski ${ }^{8}$, Przemysław Bant ${ }^{9}$, Agnieszka Lipiec ${ }^{10}$ \\ ${ }^{1}$ Allergen Research Center, Warsaw, Poland \\ ${ }^{2}$ Laboratory of Paleobotany, Department of Stratigraphical Geology, Institute of Geological Sciences, \\ University of Wroclaw, Poland \\ ${ }^{3}$ Institute of Marine \& Environmental Sciences, University of Szczecin, Poland \\ ${ }^{4}$ Department of Botany and Plant Physiology, University of Life Sciences in Lublin, Poland \\ ${ }^{5}$ Department of Clinical and Environmental Allergology, Medical College, Jagiellonian University, Cracow, Poland \\ ${ }^{6}$ Faculty of Natural Sciences, Institute of Earth Sciences, University of Silesia in Katowice, Poland \\ ${ }^{7}$ Pediatrics, Gastroenterology and Allergology Department, University Children Hospital, \\ Medical University of Bialystok, Poland \\ ${ }^{8}$ Department of Otolaryngology with Division of Cranio-Maxillo-Facial Surgery, Military Institute of Medicine, \\ Warsaw, Poland \\ ${ }^{9}$ Department of Otolaryngology with Division of Cranio-Maxillo-Facial Surgery, Military Institute of Medicine, \\ Warsaw, Poland \\ ${ }^{10}$ Department of Prevention of Environmental Hazards, Allergology and Immunology, \\ Medical University of Warsaw, Poland
}

\begin{abstract}
:
The study aims to monitor the alder pollen season in selected Polish cities: Bialystok, Cracow, Lublin, Olsztyn, Opole, Piotrkow Trybunalski, Sosnowiec, Szczecin, Warsaw, Wroclaw and Zielona Gora in 2021. Pollen concentrations were recorded by volumetric method using a Burkard-type sampler operating in a continuous volumetric mode. Alder pollen season, defined as the period with $98 \%$ of the annual total catch, started in

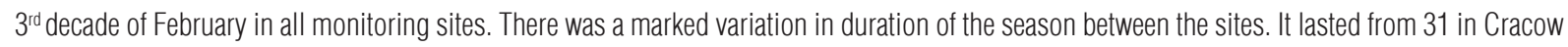
to 54 days in Bialystok (38 days on average). The highest peak daily alder pollen concentrations were observed in Wroclaw $\left(1879 \mathrm{grains} / \mathrm{m}^{3}\right)$ on February 26 $6^{\text {in)}}$. The longest exposure to high concentrations of alder pollen, lasting 22-24 days, was detected in Zielona Gora, Piotrkow Trybunalski and Olsztyn. The alder pollen season in 2021, compared to the previous year, was longer, with higher average sum of daily concentrations over the season, higher maximum daily concentrations and longer exposure to high pollen concentrations at most monitoring sites.
\end{abstract}

Key words: alder (Alnus), pollen concentration, allergens

\section{Introduction}

The genus Alder (Alnus Mill.) belongs to the order Fagales Engl. and family Betulaceae Gray [1]. Black alder A. glutinosa is common throughout Poland, except in areas at higher elevations. Gray alder A. incana is not as common, occurring mainly in the mountains and along the Vistula River and from Suwalskie Lakeland to Tuchola Forests [2].

It is an early flowering tree. The occurrence of alder pollen in the air is significantly influenced by meteorological factors [3]. Together with birch and hazel pollen, it is an important source of tree pollen allergens 
in the temperate climate zone of the Northern Hemisphere. In a European GA2LEN study, conducted in 14 European countries, the percentage of patients sensitized to alder (with positive skin prick test) ranged from $3.1 \%$ to $47.0 \%$ and the percentage with clinically relevant symptoms ranged from $2.3 \%$ to $36.2 \%$ [4].

The marker of sensitization to alder, its main allergen, is the Aln $g 1$ molecule, belonging to the PR-10 family of proteins (Bet $v 1$ homologues), to which $100 \%$ of alder sensitized patients react [5]. The Aln $g 2$ molecule, another alder allergen, belongs to the profilin family, proteins that are panallergens in the plant kingdom. The high degree of structural similarity within the above families of proteins lies at the basis of cross-reactivity, whereby a person allergic to alder pollen may also react to pollen of other members of the Fagales as well as to some fruits, vegetables and nuts (pollen-related food allergy/oral allergy syndrome) [6]. The Aln $g 4$ molecule, which belongs to the family of polkalcins, is recognized by the antibodies of $18 \%$ of alder allergy sufferers [5].

\section{Aim}

The study aims to compare the alder pollen season in selected Polish cities: Bialystok, Cracow, Lublin, Olsztyn, Opole, Piotrkow Trybunalski, Sosnowiec, Szczecin, Warsaw, Wroclaw and Zielona Gora in 2021 .

\section{Material and method}

The pollen count measurements were conducted during the 2021 pollen season. Pollen concentrations were recorded, in line with international standards, by volumetric method using a Burkard-type sampler operating in a continuous volumetric mode [7]. Counts were recorded over 7-day cycles and microscopic analysis was performed for each 24-hour period.

The following variables were taken into consideration:

- length of the alder pollen season, determined by the $98 \%$ method, calculated based on the beginning and end of the season defined by $1 \%$ and $99 \%$ of the annual total pollen catch, respectively [8]

- sum of the daily average pollen concentrations over the season expressed by the seasonal pollen integral (SPI) [9]

- maximum daily pollen concentration for the season and date of the highest

- the number of days with above-threshold pollen level, adopted according to the available literature.

Alder pollen concentrations were expressed as the number of pollen grains in $1 \mathrm{~m}^{3}$ of air per day (grains $/ \mathrm{m}^{3}$ ). On the basis of the literature, the number of days when the concentrations of Alnus pollen exceeded the threshold values for the development of allergy symptoms were determined [10] (tab. 1).

\section{Results and discussion}

In 2021, the alder pollen season began between February $21^{\text {st }}$ in Zielona Gora and $27^{\text {th }}$ in Olsztyn and lasted until even the $3^{\text {rd }}$ decade of April (in Bialystok) (tab. 1, fig. 1, 2). In 2021 the onset of the season occurred almost a month later than in the previous year and at a similar time as in years 2019 and 2017 [11-14]. As the beginning of alder pollen season depends on weather conditions, mainly the accumulated air temperature, the length of the season may vary in individual years by 30 up to 50 days. The average length of the alder pollen season in 2021 was 38 days. It falls between the length of the season in 2019 (22 days)

Table 1. Characteristics of Alnus pollen season in 2021.

\begin{tabular}{|c|c|c|c|c|c|c|c|c|c|c|c|}
\hline $\begin{array}{c}\text { Feature of pollen } \\
\text { season }\end{array}$ & Olsztyn & Opole & $\begin{array}{l}\text { Piotrkow } \\
\text { Trybunalski }\end{array}$ & Szczecin & Sosnowiec & Lublin & Warsaw & Bialystok & Wroclaw & Cracow & $\begin{array}{l}\text { Zielona } \\
\text { Gora }\end{array}$ \\
\hline $\begin{array}{l}\text { Duration of pollen } \\
\text { season (number } \\
\text { of days) }\end{array}$ & $\begin{array}{l}27.02- \\
6.04 \\
(39)\end{array}$ & $\begin{array}{l}23.02- \\
28.03 \\
(34)\end{array}$ & $\begin{array}{l}24.02-29.03 \\
(34)\end{array}$ & $\begin{array}{l}22.02- \\
27.03 \\
(34)\end{array}$ & $\begin{array}{l}24.02-9.04 \\
(45)\end{array}$ & $\begin{array}{l}25.02- \\
8.04 \\
(43)\end{array}$ & $\begin{array}{l}24.02- \\
29.03 \\
(34)\end{array}$ & $\begin{array}{l}25.02- \\
19.04 \\
(54)\end{array}$ & $\begin{array}{l}23.02- \\
29.03 \\
(35)\end{array}$ & $\begin{array}{l}25.02- \\
27.03 \\
(31)\end{array}$ & $\begin{array}{l}21.02- \\
26.03 \\
(34)\end{array}$ \\
\hline $\begin{array}{l}\text { Seasonal pollen } \\
\text { integral (SPI) }\end{array}$ & 10978 & 9818 & 9773 & 8047 & 3014 & 6631 & 9170 & 3205 & 7913 & 2185 & 11402 \\
\hline $\begin{array}{l}\text { Peak value and } \\
\text { peak date }\end{array}$ & $\begin{array}{l}1786 \\
(17.03)\end{array}$ & $\begin{array}{l}1709 \\
(26.02)\end{array}$ & $\begin{array}{l}1564 \\
(26.02)\end{array}$ & $\begin{array}{l}1784 \\
(3.03)\end{array}$ & 451 (27.02) & $\begin{array}{l}951 \\
(16.03)\end{array}$ & $\begin{array}{l}1346 \\
(26.02)\end{array}$ & $\begin{array}{l}618 \\
(26.03)\end{array}$ & $\begin{array}{l}1879 \\
(26.02)\end{array}$ & $\begin{array}{l}407 \\
(27.02)\end{array}$ & $\begin{array}{l}1638 \\
(4.03)\end{array}$ \\
\hline $\begin{array}{l}\text { Days } \geq 45 \text { pollen/ } \\
\mathrm{m}^{3}[10]\end{array}$ & 32 & 24 & 28 & 23 & 16 & 25 & 27 & 14 & 17 & 17 & 24 \\
\hline $\begin{array}{l}\text { Days } \geq 85 \text { pollen/ } \\
\mathrm{m}^{3}[10]\end{array}$ & 24 & 18 & 23 & 19 & 11 & 18 & 21 & 10 & 14 & 7 & 22 \\
\hline
\end{tabular}


and in 2016 (50 days). The shortest season was recorded in Cracow (31 days), while the longest in Bialystok (54 days) (tab. 1, fig. 3, 4) $[12,15]$.

The highest daily alder pollen concentration was detected in Wroclaw (1879 grains $/ \mathrm{m}^{3}$ on February $26^{\text {th }}$ ), followed by records in Olsztyn (1786 grains $/ \mathrm{m}^{3}$ on March $17^{\text {th }}$ ) and Szczecin (1784 grains $/ \mathrm{m}^{3}$ on March $3^{\text {rd }}$ ) (tab. 1, fig. 1, 3, 5). The maximum daily concentrations in 2021 were much higher in comparison to those detected in 2020 (tab. 1) [11]. The lowest peak daily alder pollen concentrations were recorded in Cracow (407 grains $/ \mathrm{m}^{3}$ on February $27^{\text {th }}$ ) and in Sosnowiec (451 grains $/ \mathrm{m}^{3}$ on February $27^{\text {th }}$ ) (tab. 1 , fig. 3, 6).

The highest annual sum of alder pollen grains (SPI) in 2021 was recorded in Zielona Gora (11,402 grains), while the lowest in Cracow (2185 grains) (tab. 1). The average SPI for alder pollen season in 2021 was 7467 . It was three times higher than in 2020 $(2,447)$ but two times lower than in $2019(12,485)$ $[11,12]$.

The highest risk of pollen allergy expressed in days with pollen levels exceeding the threshold value at which first symptoms of allergy occur (45 grains/ $\mathrm{m}^{3}$ ) was recorded in Olsztyn (32 days) and in Warsaw as well as in Zielona Gora (27-28 days respectively). For other monitoring sites the number of days with alder pollen concentrations exceeding the threshold of first allergy symptoms was between 14 and 25 days (tab. 1) [10].

The longest exposure to high concentrations of alder pollen ( 85 grains $/ \mathrm{m}^{3}$ and above) causing severe clinical symptoms, lasting 22-24 days, was recorded

Figure 1. Alder pollen concentration in Olsztyn and Opole in 2021.

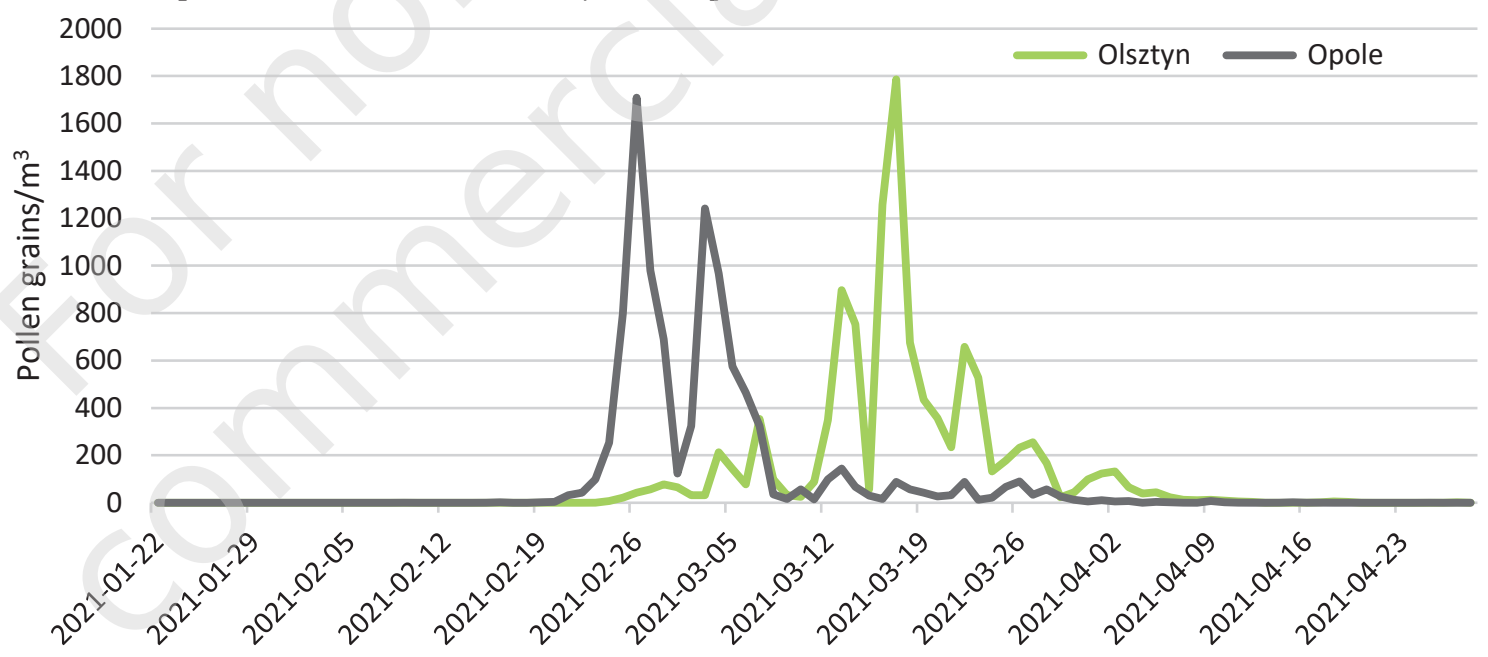

Figure 2. Alder pollen concentration in Zielona Gora in 2021. 1800

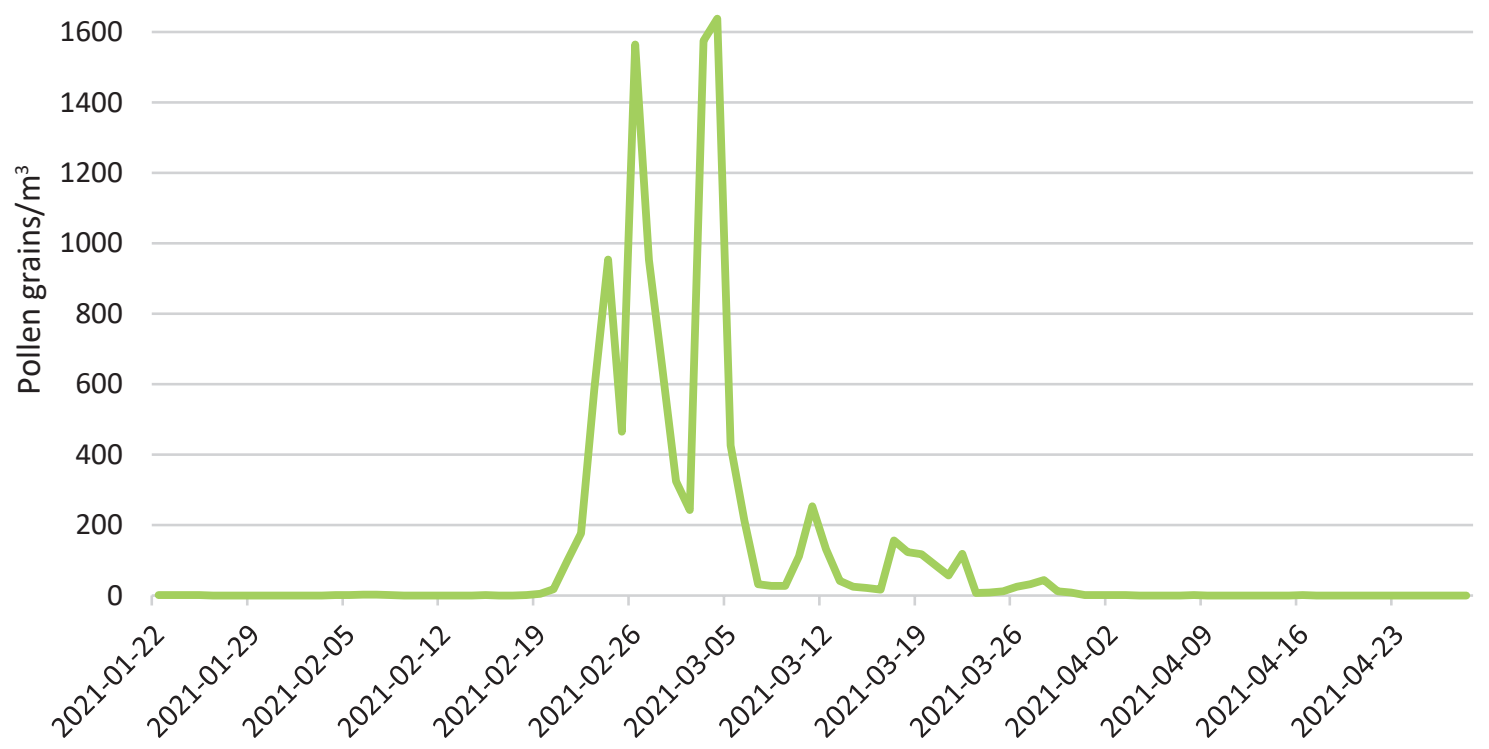


Figure 3. Alder pollen concentration in Wroclaw and Cracow in 2021.

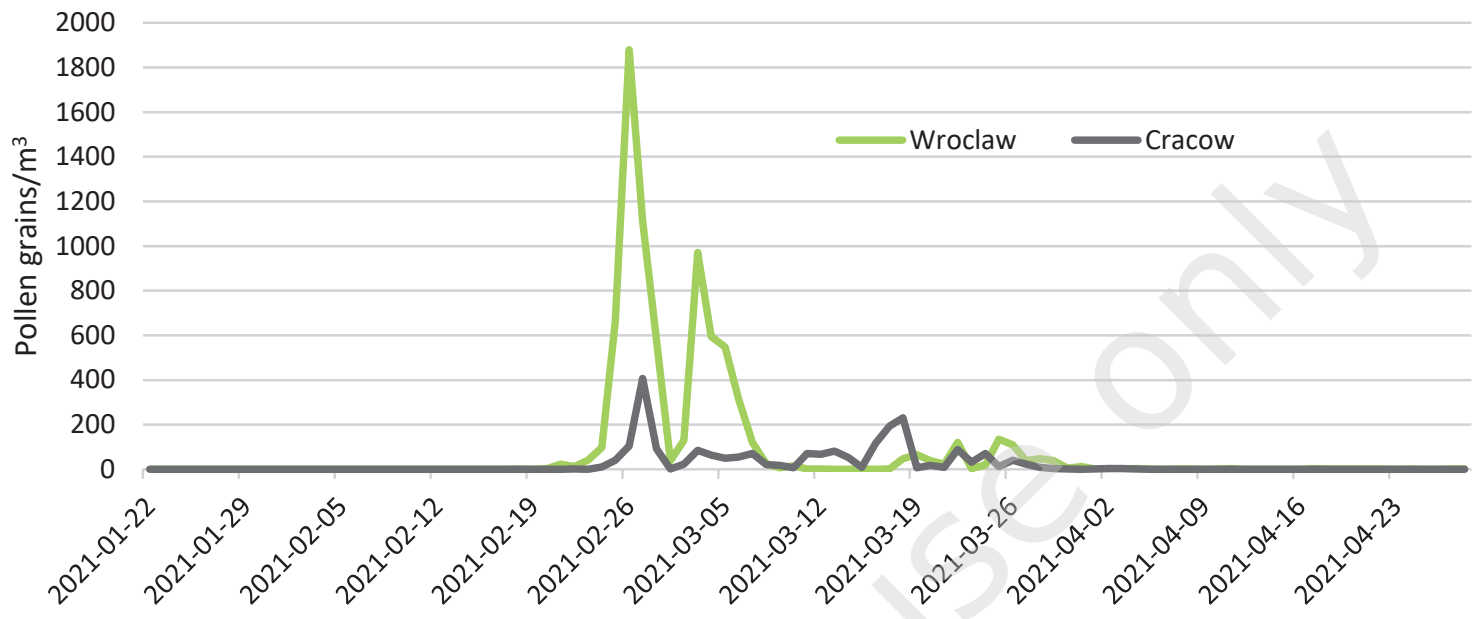

Figure 4. Alder pollen concentration in Warsaw and Bialystok in 2021.

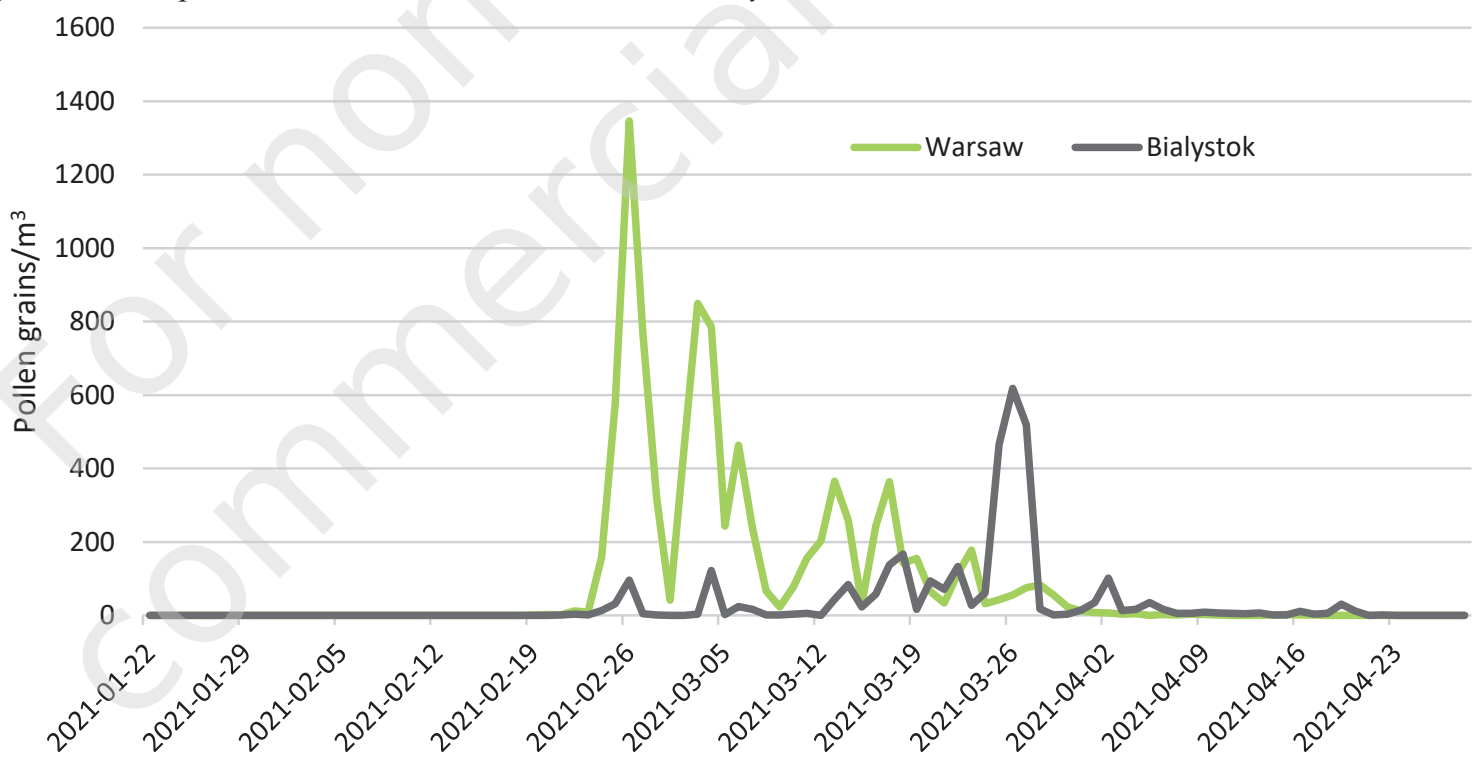

Figure 5. Alder pollen concentration in Piotrkow Trybunalski and Szczecin in 2021.

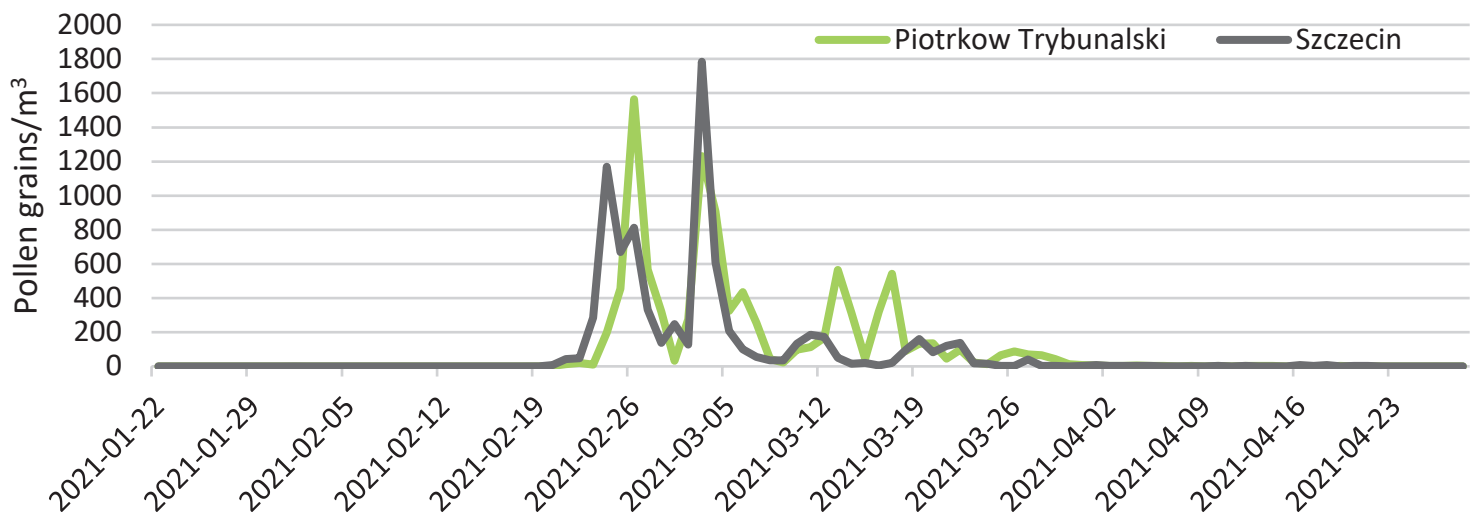

in Zielona Gora, Piotrkow Trybunalski and Olsztyn (tab. 1). Those records were higher than in the previous year, when number of days with concentrations of alder pollen equal or above the threshold $\left(85\right.$ grains $\left./ \mathrm{m}^{3}\right)$ did not exceed 16 [11]. 
Figure 6. Alder pollen concentration in Sosnowiec and Lublin in 2021.

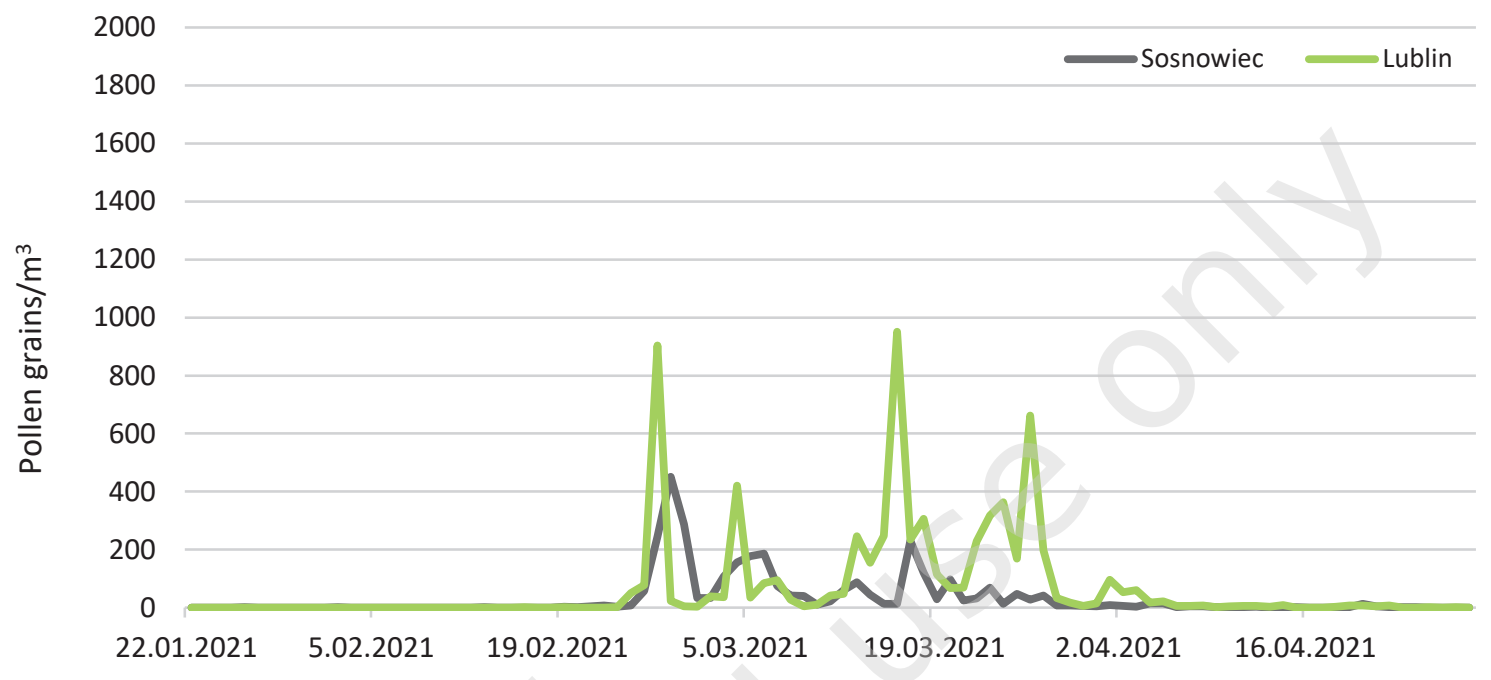

\section{Conclusions}

The alder pollen season in 2021 began in $3^{\text {rd }}$ decade of February. There was a marked variation in duration of the season between monitoring sites. It lasted from 31 days in Cracow to 54 days in Bialystok (38 days on average).

The highest peak concentrations of alder pollen were detected in Wroclaw, Opole, Szczecin and Olsztyn, whereas the lowest in Cracow, Sosnowiec and Bialystok. The longest exposure to high concentrations of alder pollen, lasting 22-24 days, was detected in Zielona Gora, Piotrkow Trybunalski and Olsztyn.

The alder pollen season in 2021, compared to the season in 2020, was characterized by longer average pollen season, higher average sum of daily concentrations over the season (SPI), higher maximum daily concentrations and longer exposure to high concentrations of alder pollen in the majority of monitoring sites.

\section{References}

1. Bremer B, Bremer K, Chase M. An update of the Angiosperm Phylogeny Group classification for the orders and families of flowering plants: APG III. Bot J Linean Soc. 2009; 161(2): 105-21.

2. Zajac A, Zając M (ed). Distribution Atlas of Vascular Plant of Poland. Pracownia Chorologii Komputerowej, Instytut Botaniki UJ, Cracow 2001.

3. Puc M, Kasprzyk I. The patterns of Corylus and Alnus pollen seasons and pollination periods in two Polish cities located in different climatic regions. Aerobiologia. 2013; 29: 495-511.

4. Burbach GJ, Heinzerling LM, Edenharter G et al. GA(2)LEN skin test study II: clinical relevance of inhalant allergen sensitizations in Europe. Allergy. 2009; 64: 1507-15.
5. Matricardi PM, Kleine-Tebbe J, Hoffmann HJ et al. EAACI Molecular Allergology. User's Guide. Pediatr Allergy Immunol. 2016; 27(suppl 23): 1-250.

6. Werfel T, Asero R, Ballmer-Weber BK et al. Position paper of the EAACI: food allergy due to immunological cross-reactions with common inhalant allergens. Allergy. 2015; 70: 1079-90.

7. Mandrioli P, Comtois P, Dominguez Vilches E et al. Sampling: Principles and Techniques. In: Mandrioli P, Comtois $P$, Levizzani V (ed). Methods in Aerobiology. Pitagora Editrice, Bologna 1998: 47-112.

8. Emberlin J, Savage M, Jones S. Annual variations in grass pollen seasons in London 1961-1990: trends and forecast models. Clin Exp Allergy. 1993; 23(11): 911-8.

9. Galan C, Artaitti A, Bonnini M et al. Recommended terminology for aerobiological studies. Aerobiologia. 2017; 33: 293-5 .

10. Rapiejko P, Stankiewicz W, Szczygielski K et al. Threshold pollen count necessary to evoke allergic symptoms. Otolaryngol Pol. 2007; 61(4): 591-4.

11. Malkiewicz M, Piotrowska-Weryszko K, Puc M et al. Alder pollen season in selected cities of Poland in 2020. Alergoprofil. 2020; 16(2): 25-30.

12. Malkiewicz M, Puc M, Stacewicz A et al. Alder pollen season in selected cities of Poland in 2019. Alergoprofil. 2019; 15(1): 22-6.

13. Puc M, Lipiec A, Kotrych D et al. Alder pollen season in northern Poland in 2017. Alergoprofil. 2017; 13(2): 77-80.

14. Piotrowska-Weryszko K, Rapiejko P, Weryszko-Chmielewska $E$ et al. Alnus pollen season in selected cities of Poland in 2017. Alergoprofil. 2017; 13(2): 81-4.

15. Puc M, Rapiejko P, Lipiec A et al. The analysis of alder pollen season in northern Poland in 2016. Alergoprofil. 2016; 12(2): 92-6. 
Author's contributions:

A. Rapiejko: 50\%; A. Lipiec 10\%; other authors: $5 \%$ each.

Conflict of interests:

Financial support:

Ethics: The contents presented in this paper are compatible with the rules the Declaration of

Helsinki, EU directives and standardized requirements for medical journals.

Copyright: (C) Medical Education sp. z 0.0. This is an Open Access article distributed under the terms of the Attribution-NonCommercial 4.0 International (CC BY-NC 4.0). License (https://creativecommons.org/licenses/by-nc/4.0/), allowing third parties to copy and redistribute the material in any medium or format and to remix, transform, and build upon the material, provided the original work is properly cited and states its license.

ORCID

A. Rapiejko - ID - http://orcid.org/0000-0002-8906-2405

M. Malkiewicz - ID - http://orcid.org/0000-0001-6768-7968

T. Wolski - ID - http://orcid.org/0000-0002-1368-6107

A. Konarska - ID - http://orcid.org/0000-0003-2174-7608

M. Ziemianin - ID - http://orcid.org/0000-0003-4568-8710
G. Siergiejko - ID - http://orcid org/0000-0003-4084-8332

K. Szczygielski - ID - http://orcid.org/0000-0002-3717-5424

P. Bant - ID - http://orcid.org/0000-0002-1697-3152

A. Lipiec - ID - http://orcid.org/0000-0003-3037-2326

\section{Correspondence:}

Agnieszka Lipiec, MD, PhD, D.H.Sc.

Department of Prevention of Environmental Hazards, Allergology and Immunology,

Medical University of Warsaw

02-091 Warszawa, ul. Banacha 1A

e-mail: alipiec@wum.edu.pl

c) Medical Education. For private and non-commercial use only. Downloaded from https://www.journalsmededu.pl/index.php/alergoprofil: 26.04.2023; 01:44,32 